\title{
NEW CONTRIBUTIONS TO THE KNOWLEDGE OF LEPIDORTERA FAUNA OF KOSOVO AND METOHIA (REPUBLIC OF SERBIA)
}

\section{Predrag Jakšić ${ }^{1 *}$}

${ }^{1}$ Faculty of Sciences and Mathematics, University of Niš, Niš, Serbia.

\begin{abstract}
Seven species of Lepidoptera - Triodia sylvina (Linnaeus, 1761), Trichiura crataegi (Linnaeus, 1758), Eriogaster lanestris (Linnaeus, 1758), Endromis versicolora (Linnaeus, 1758), Caradrina clavipalpis (Scopoli, 1763), Polymixis rufocincta (Gayer, 1828) and Oria musculosa (Hübner, 1808) were recorded for the first time in Kosovo and Metohia, Republic of Serbia. The next seven

species- Trichiura crataegi (Linnaues, 1758), Lycia graecarius (Staudinger, 1861), Biston strataria (Hufnagel, 1767), Agriopis aurantiaria (Hübner, 1799), Erannis defoliaria (Clerck, 1759), Parasemia plantaginis (Linnaeus, 1758) and Euplagia quadripunctaria (Poda, 1761) were confirmed for the same area. Besides detailed faunistic data, illustrations of some adults are given.
\end{abstract}

Key words: Lepidoptera, Kosovo and Metohia.

\section{INTRODUCTION}

The initial papers on Lepidoptera for Kosovo and Metohia were published at beginning of the XX Century by Dr. Hans Rebel, one of the leading European lepidopterist from Nat. Hist. Museum in Wien. Rebel published four papers in the German language on the Lepidoptera of Metohia ((Rebel, 1910), (Rebel 1914), (Rebel 1917a) and (Rebel 1917b)).

Rebel for the first time describe a new taxa from Kosovo and Metohia: Zygaena exulans apfelbecki (Rebel, 1910) from Ljuboten, Šar-Planina Mt. In few last decades new contributions were given by Djordjije Djorović ((Djorović, 1974a; 1974b), (Djorović, 1975), (Djorović 1992) and Predrag Jakšić (Jakšić, 1987; 1999; 2003), (Jakšić \& Ristić, 1999), (Jakšić \& Dimović, 2000).

\section{MATERIAL AND METHODS}

Specimens were collected using butterfly net and Philips $250 \mathrm{~W}$ mercury light bulb trap. The positions and coordinates at which the Lepidoptera were caught were determined using Garmin e-Trex Vista Gps device (Table 1).

The photos of specimens were taken by Nikon Camera with AF-S Micro Nikkor Lens (Table 2). Genitalia from few moth specimens were dissected and microscope slides were used for reliable identification of a specific taxa.
((Fibiger et al., 1990-2010), (Fibiger \& Lafontaine, 2005), (Forster \& Wohlfahrt's, 19601981), as well as (Hausmann et al., 2001-2015) were used for species identification. The taxonomic order and nomenclature were done according to ((Karsholt \& Razowski, 1996) and (Van Nieukerken et al., 2011) for high level taxa.

\section{RESULTS AND DISCUSSION}

Fam. Hepialide 63. Triodia sylvina (Linnaeus, 1761)

Material examined: Šar-Planina Mt, Stojkova kuća, 1750 m, 1.VIII 1973., 1 đ̄, Jakšić P. leg.; Priština, Grmija Mt., 700 m., 30 VIII 1973., 2 ふ઼, 3 qㅇ, Jakšić P. leg.; 20. IX 1986., 1일 Jakšić P. leg. This is a new distribution records in Kosovo and Metohia. Species is distributed in Serbia.

This larva feeds on various plants roots, including Echium vulgare, Taraxacum, Pteridum and Rumex. This species overwinters twice as a larva.

Fam. Lasiocampidae

6731. Trichiura crataegi (Linnaeus, 1758)

The literature data (Djorović, 1992): Mojstir, Crnoljevo.

Material examined: Novo Brdo, Bostane, $800 \mathrm{~m}$, 20.IX 1984,1ð̂, Jakšić P. leg. (Tab 2: 1). 
Table 1. List of sampling sites.

\begin{tabular}{|l|c|c|c|c|}
\hline \multicolumn{1}{|c|}{ SAMPLING SITES } & ELEVATION (m) & UTM & \multicolumn{2}{c|}{ COORDINATES } \\
\cline { 3 - 5 } & & & $\begin{array}{c}\text { Latitude } \\
\varphi(\mathrm{N})\end{array}$ & $\begin{array}{c}\text { Longitude } \\
\lambda(\mathrm{E})\end{array}$ \\
\hline Novo Brdo, Bostane & & & $42^{\circ} 36^{\prime} 00^{\prime \prime}$ & $21^{\circ} 25^{\prime} 38^{\prime \prime}$ \\
\hline Peć, Miliševac & 850 & EN31 & $42^{\circ} 39^{\prime} 40^{\prime \prime}$ & $20^{\circ} 15^{\prime} 10^{\prime \prime}$ \\
\hline Priština, Babin Most & $500-600$ & DN32 & $42^{\circ} 44^{\prime} 47^{\prime \prime}$ & $21^{\circ} 04^{\prime} 58^{\prime \prime}$ \\
\hline Priština, Grmija Mt. & 580 & EN03 & $42^{\circ} 40^{\prime} 30^{\prime \prime}$ & $21^{\circ} 11^{\prime} 54^{\prime \prime}$ \\
\hline Priština, town & 700 & EN12 & $42^{\circ} 39^{\prime} 48^{\prime \prime}$ & $21^{\circ} 09^{\prime} 28^{\prime \prime}$ \\
\hline Šar-Planina Mt, Blateštičko Jezero & 2200 & EM07 & $42^{\circ} 11^{\prime} 28^{\prime \prime}$ & $21^{\circ} 04^{\prime} 24^{\prime \prime}$ \\
\hline Šar-Planina Mt, Dovedenica & 1550 & EM07 & $42^{\circ} 10^{\prime} 08^{\prime \prime}$ & $20^{\circ} 57^{\prime} 49^{\prime \prime}$ \\
\hline Šar-Planina Mt, Mekuš Bor & 1700 & DM96 & $42^{\circ} 12^{\prime} 23^{\prime \prime}$ & $21^{\circ} 04^{\prime} 11^{\prime \prime}$ \\
\hline Šar-Planina Mt, Rudoka & 2400 & DM73 & $41^{\circ} 56^{\prime} 35^{\prime \prime}$ & $20^{\circ} 47^{\prime} 59^{\prime \prime}$ \\
\hline Šar-Planina Mt., Stojkova Kuća & 1750 & EM07 & $42^{\circ} 10^{\prime} 51^{\prime \prime}$ & $21^{\circ} 02^{\prime} 01^{\prime \prime}$ \\
\hline
\end{tabular}

Table 2. Examined species.

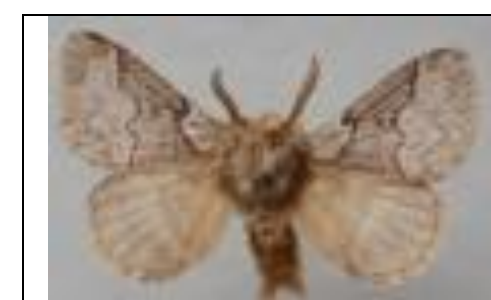

1. Trichiura crataegi (Linnaeus, 1758)

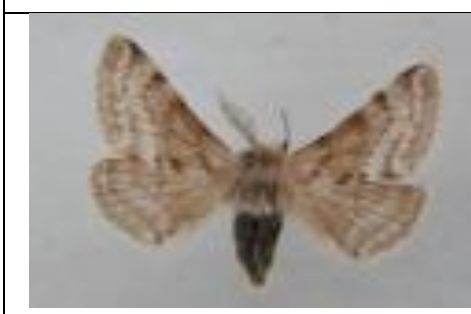

4. Lycia graecarius (Staudinger, 1861);

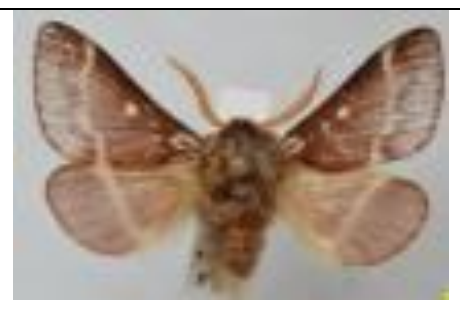

2. Eriogaster lanestris (Linnaeus, 1758)

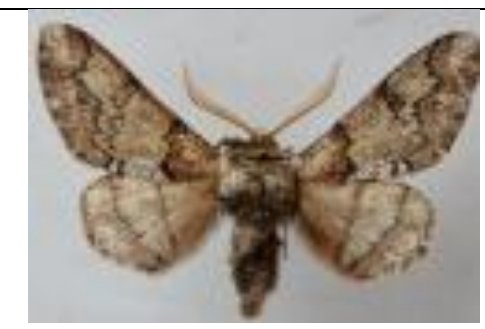

5. Biston strataria (Hufnagel, 1767)

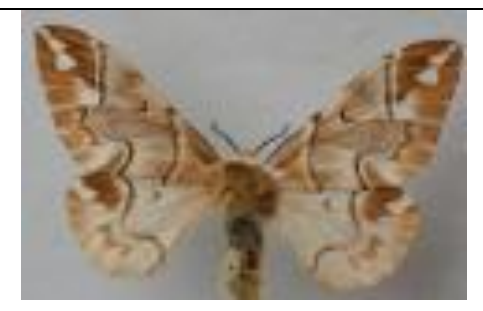

3. Endromis versicolora (Linnaeus, 1758)

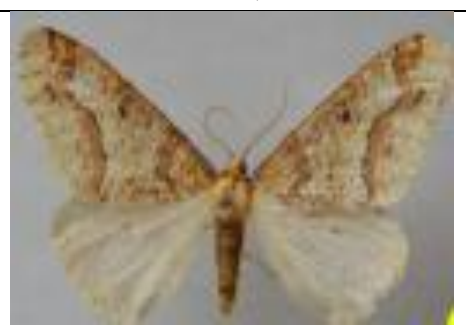

6. Erannis defoliaria (Clerck, 1759)

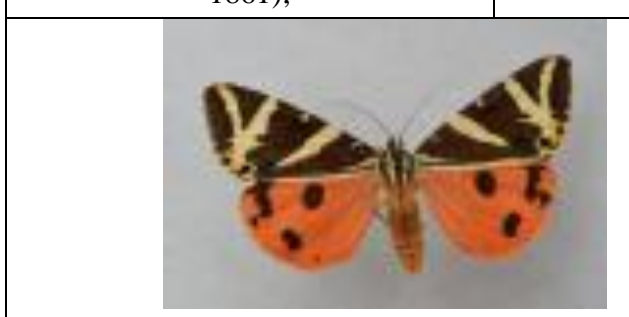

7. Euplagia quadripunctaria (Poda, 1761)

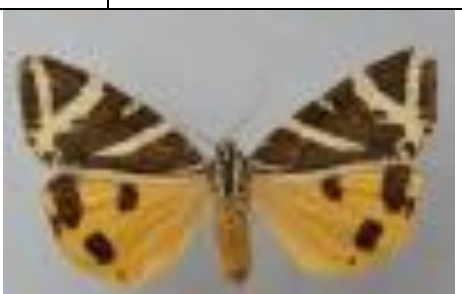

8. E. quadripunctaria forma lutescens Staudinger, 1861
Species is distributed in Serbia. The larval foodplants are Betula verrucosa, Betula pubescens, Betula nana, Alnus incana, Salix species, Populus tremula, Sorbus, aucuparia, Crataegus species, Prunus padus, and Vaccinium species

6738. Eriogaster lanestris (Linnaeus, 1758)
Material examined: Priština, Grmija 700 m, 20.III 1980.,1ð̂, Jakšić P. leg. Tab 2:2). This is a new faunistic record from Kosovo and Metohia. Species is distributed in Serbia. The larvae feed on Prunus spinosa and Crataegus. This plant species are present in the area (Krivošej, 2013).The pupae may stay unhatched for years. 
6769. Cosmotriche lobulina ([Denis \& Schiffermüller], 1775) [syn.: lunigera (Esper,), 1784]

Material examined: Priština, Grmija Mt., 700 m, 22. VI 1974., 1 J, Jakšić P. leg. This is a new faunistic record from Kosovo and Metohia. Species is distributed in Serbia. The caterpillars feed on different conifer species: Abies, Pinus, Picea.

Fam. Endromidae

6784. Endromis versicolora (Linnaeus, 1758)

Material examined: Novo Brdo, Bostane, $800 \mathrm{~m}$, 6.IV 1982, 1ठ઼, Jakšić P.leg. (Tab. 2:3). This is a new faunistic record from Kosovo and Metohia.

Species is distributed in Serbia.

The caterpillars food plants is Betula, as well as Alnus, Corylus, and Tilia.

Fam. Geometridae

7676. Lycia graecarius (Staudinger, 1861)

The literature data: (Jakšić \& Ristić, 1999) are this species incorrectly listed under the name Lycia zonaria (Denis \& Schiffermüller, 1775).

Material examined: Priština, Grmija, 700 m, 15.III 1979., 1ð̃, Jakšić P. leg. (Tab. 2:5).

Species is distributed in Serbia. This species is polyphagous on deciduous trees.

7685. Biston strataria (Hufnagel, 1767)

The literature data: (Djorović, 1992): Birač, Garačevo, Mojstir, Crnoljevo.

Material examined: Priština, Grmija, 700 m, 15.III 1979., 1 ô, Jakšić P. leg. (Tab. 2: 5). Species is distributed in Serbia. This species is polyphagous on deciduous trees.

7695. Agriopis aurantiaria (Hübner, 1799)

The literature data: (Djorović, 1992): Birač (Suva Reka), Garačevo, Mojstir.

Material examined:Priština, Grmija, 700 m, 15.X 1979., 1ठ̃, Jakšić P. leg. Species is distributed in Serbia. Foodplant(s): Betalaceae and Rosaceae: polyphagous on deciduous trees.

7699. Erannis defoliaria (Clerck, 1759)

The literature data: (Djorović, 1992): Birač (Suva Reka), Garačevo, Mojstir, Crnoljevo.

Material examined: Novo Brdo, Bostane, 800 m, 27.XI 1982., 2 ふึર, Jakšić P. leg. (Tab. 2: 6). Species is distributed in Serbia. Caterpillars are recorded on more than 20 plant species.

8274. Epirrhoe tristata (Linnaeus, 1758)

Material examined: Šar-Planina Mt, Devedenica, 1300 m 21. VI 1995., 1ðَ, Jakšić P. leg ; Šar-Planina Mt., Blateštičko Jezero, 2200 m, 25.VI 1997., 6ふึَ, Jakšić P. leg. This is a new distributional record in Kosovo and Metohia. Species is distributed in Serbia.
Larva monophagous on Gallium (Rubiaceae), (Janković, 1982) reported Galium silvaticum, $G$. erectum and G. anisophyllum on Šar-Planina Mt.

Fam. Noctuidae

9433. Caradrina clavipalpis (Scopoli, 1763)

Material examined: Priština, Grmija Mt., $700 \mathrm{~m} \mathrm{1 \delta}$, 22. VIII 1973.: 1§̂,, 1. IX 1978 and Novo Brdo, Bostane, 800 m, 1ð̂, 8.VI 1982., Jakšić P. leg. Genitalia slides SR-1918, SR-1933 and SR-6209. Genitalia patern is identical to the one presented by (Rezbanyai-Reser, 1986). This is a new distributional records in Kosovo and Metohia. Species is distributed in Serbia. The larvae feed on Plantago and various grasses.

9726. Polymixis rufocincta (Geyer, 1828)

Material examined: Priština, Babin Most, 580 m, 4.VI 1982., Jakšic P. leg.1 Novo Brdo, Bostane, 800 m, 17. X 1982., 1ð̄, Jakšić P. leg. This is the first faunistic records from Kosovo and Metohia. Species is distributed in Serbia

This species is polyphag on Hieracium, Silene, Dianthus, Asplenium, and Lamium.

9885. Oria musculosa (Hübner, 1808)

Material examined: Priština, 600 m, 30,VII 1991., 1ð̄, Jakšić P. leg. This is a new faunistic records from Kosovo and Metohia. Species is distributed in Serbia. The larvae feed internally in the stems of cereal crops (fam Poaceae).

Fam. Erebiidae: Arctiinae

10557. Parasemia plantaginis (Linnaeus, 1758)

The literature data: (Rebel, 1917a): Žljeb Mt., 1400-1700 m, f. lutea Tutt, hospital Schiff. and bicolor Rätz.

Material examined: Šar-Planina Mt., Rudoka, 2400 m, 27. VII 1995., 2 ổ, Jakšić P. leg.; Šar-Planina Mt., Mekuš Bor, 1700 m, 23.VI 1997., 1 đૈ, Jakšić P. leg. Species is distributed in Serbia. The species is polyphagous, on herbaceous plants: Rubus idaeus, Plantago, Leontodon and Hieracium.

10605. Euplagia quadripunctaria (Poda, 1761)

The literature data: (Rebel, 1917a): Novo Selo; (Djorović, 1974); Birač (Suva Reka); Djorović, Miliševac, 600 m,9.-10. VIII 1987., 1§, the yellow wing form lutescens Staudinger, 1861. (Tab.2:7 and 8). The caterpillars are polyphagous on Lamium, Urtica, Glechoma, Rubus, Taraxacum, Plantago and others.

(Liebert \& Brakefield, 1990) poined out that:... "the colour polymorphism in the warningly-coloured moth Callimorpha quadripunctaria (Lepidoptera: Arctidae) involves three major phenotypes with bright

\section{Biology}


red, orange and yellow hindwings. These are controlled by two unlinked gene loci, each with a pair of alleles exhibiting complete dominance. Once locus, when homozygous recessive, is epistatic to the other."

\section{CONCLUSION}

Moths representatives of the following six families have been reported: Hepialidae, Lasiocampida, Endromidae, Geometridae, Noctudae and Arctiidae. Obtained results of fourteen species contribute to the more complete faunistic knowledge of the distribution of Lepidoptera species in Kosovo and Metohia and Serbia generally

\section{REFERENCES}

Djorović, Dj. 1974. Neke važnije vrste defolijatora hrasta iz familije Tortricidae. Šumarski pregled, Skoplje, 5-6, pp. 35-43.

Djorović, Dj. 1974. Prilog poznavanju nekih vrsta defolijatora hrasta iz familije Arctiidae na Kosovu. Šumarstvo, Beograd, 10-12, pp. 19-23.

Djorović, Dj. 1975. Prilog poznavanju moljaca u hrastovim šumama na Kosovu. Zaštita bilja, 26(133), pp. 229-233.

Djorović, Dj. 1992. Biocenotički kompleks gusenica hrasta.Priština: Udruženje "Nauka i društvo" AP Kosova i Metohije., pp. 1-191.

Forster, W., \& Wohlfahrt, T. 1960. Die Schmetterlinge Mitteleuropas.Stuttgart: Franckh'sche Verlagshandlung. 1960-1981.

Jakšić, P. 1987. Specifični elementi faune Lepidoptera nekih kosovskih klisura. Priroda Kosova, Priština, 6, pp. 93-107.

Jakšić, P. 1999. Distribution of butterfly communities (Lepidoptera: Hesperioidea and Papilionoidea) in plant communities over the Jažinačko jezero lake region on Šar-planina Mt. / Distribucija zajednica dnevnih leptira (Lepidoptera: Hesperioidea \& Papilionoidea) u biljnim zajednicama na širem području Jažinačkih jezera na Šar-planini. The University Thought, Nat. Sci., Priština, 5(2), pp. 7175.

Jakšić, P., \& Dimović, D. 2000. Pregled utvrđenih vrsta rodova Eilema Hübner, (1804) i Lithosia Fabricius, 1798 Bora i susednih područja (Lepidoptera: Arctiidae, Lithosiinae) / The Review of the examined species of genera Eilema Hübner, 1819 and Lithosia Fabricius, 1798 in Bor town and surrounding area (Lepidoptera: Arctiidae, Lithosiinae). Zaštita prirode, Beograd, 52(1), pp. 4763.

Jakšić, P. 2016. Tentative Check List of Serbian Microlepidoptera. Ecologica Montenegrina, Podgorica, 7, pp. 33-258.

Jakšić, P., \& Ristić, G. 1999. New and rare species of Lepidoptera in Yugoslavia. Acta entomologica serbica, Beograd, 4(1/2), pp. 63-74. 2001.

Janković, M.M. 1982. Prilog poznavanju vegetacije Šarplanine sa posebnim osvrtom na neke značajne reliktne vrste biljaka / Contribution to the study of the vegetations of the Šarplanina Mountain with particular reference to some conspicuous relict plant species. Glasnik Instituta za botaniku i Botaničke bašte Univerziteta u Beogradu, 15(1-3), pp. 75-129. (XIII).

Karsholt, O., \& Razowski, J. 1996. The Lepidoptera of Europe. A Distributional Checklist.Stenstrup: Apollo Books.

Krivošej, Z. 2013. Flora planine Grmija kod Prištine.Univerzitet u Prištini.

Liebert, T.G., \& Brakefield, P.M. 1990. The genetics of colour polymorphism in the aposematic Jersey Tiger Moth Callimorpha quadripunctaria. Heredity, 64(1), pp. 87-92. doi:10.1038/hdy.1990.11

Rebel, H. 1910. Bericht der Sektion für Lepidopterologie. II. Derselbe gibt die Beschreibung zweier neuer Lepidoptetren-formen aus Albanien bekannt. Verhandlungen der zoologisch-botanischen Gesellschaft in Wien, 60(4-6). fig 1.

Rebel, H. 1914. Lepidopteren aus dem NordalbanischMontenegrinischen Granzgebiete. Sitzungsberichte der Kaiserlichen Akademie der Wissenschaften in Wien, 23(1), pp. 1111-1128.

Rebel, H. 1917. Lepidopteren aus Neumontenegro. Sitzungsberichte, Abteilung 1, Kaiserliche Akademie der Wissenschaften in Wien. Mathematisch-naturwissenschaftliche Klasse, 126, pp. 765-813.

Rebel, H. 1917. Neue Lepidopterenfunde in Nordalbanien, Mazedonien und Serbien. ahresbericht des Naturwissenschaftlichen Orientvereins, 21, pp. 17-24.

Rezbanyai-Reser, L. 1986. Caradrina ingrate Staudinger, 1897, eine schwer erkennbare neue Wanderfalterart in Mitteleuropa. Atalanta, 17(1-4), pp. 151-156.

\footnotetext{
*E-mail: jaksicpredrag@gmail.com
} 